\title{
Uncertainties in satellite remote sensing of aerosols and impact on monitoring its long-term trend: a review and perspective
}

\author{
Z. Li ${ }^{1, *}$, X. Zhao ${ }^{2}$, R. Kahn ${ }^{3}$, M. Mishchenko ${ }^{4}$, L. Remer ${ }^{3}$, K.-H. Lee ${ }^{1}$, M. Wang ${ }^{5}$, I. Laszlo ${ }^{5}$, T. Nakajima ${ }^{6}$, and \\ H. Maring ${ }^{7}$ \\ ${ }^{1}$ Dept of Atmos. \& Oceanic Sci., UMCP, MD, USA \\ ${ }^{2}$ NOAA/NESDIS/NCDC, Asheville, NC, USA \\ ${ }^{3}$ NASA/GSFC, Greenbelt, MD, USA \\ ${ }^{4}$ NASA/GISS, New York, NY, USA \\ ${ }^{5}$ NOAA/NESDIS/STAR, Camp Spring, MD, USA \\ ${ }^{6}$ Center for Climate System Research, University of Tokyo, Japan \\ ${ }^{7}$ NASA/HQ, Washington D.C., USA \\ *also at: Inst. Of Atmos. Physics \& Nanjing University of Information Science and Technology, China
}

Received: 27 March 2009 - Accepted: 22 June 2009 - Published: 10 July 2009

\begin{abstract}
As a result of increasing attention paid to aerosols in climate studies, numerous global satellite aerosol products have been generated. Aerosol parameters and underlining physical processes are now incorporated in many general circulation models (GCMs) in order to account for their direct and indirect effects on the earth's climate, through their interactions with the energy and water cycles. There exists, however, an outstanding problem that these satellite products have substantial discrepancies, that must be lowered substantially for narrowing the range of the estimates of aerosol's climate effects. In this paper, numerous key uncertain factors in the retrieval of aerosol optical depth (AOD) are articulated for some widely used and relatively long satellite aerosol products including the AVHRR, TOMS, MODIS, MISR, and SeaWiFS. We systematically review the algorithms developed for these sensors in terms of four key elements that influence the quality of passive satellite aerosol retrieval: calibration, cloud screening, classification of aerosol types, and surface effects. To gain further insights into these uncertain factors, the NOAA AVHRR data are employed to conduct various tests, which help estimate the ranges of uncertainties incurred by each of the factors. At the end, recommendations are made to cope with these issues and to produce a consistent and unified aerosol database of high quality for both environment monitoring and climate studies.
\end{abstract}

Correspondence to: $\mathrm{Z}$. $\mathrm{Li}$

(zli@atmos.umd.edu)
Keywords. Atmospheric composition and structure (Aerosols and particles) - History of geophysics (Atmospheric sciences) - Meteorology and atmospheric dynamics (Radiative processes)

\section{Introduction}

Industrialization and human activities have led to the release of excessive amounts of trace gases and aerosol particles into the atmosphere. Aerosols are a major atmospheric variable influencing both the transfer of radiative energy, and the conversion of water vapor into cloud droplets and raindrops. As such, most general circulation models (GCMs) are now incorporating aerosol parameters and physical processes linking aerosols with the energy and water cycles so that aerosol's direct and indirect effects on climate can be addressed. However, aerosol remains one of the largest uncertainties in estimating climate forcing (IPCC, 2007), due in large part to a lack of reliable measurements on the global scale. Many global estimates of the aerosol climate forcing were based on simulations by chemical-transport model (CTM) coupled with or driven by GCM (Chin et al., 2002; Hansen et al., 2002; Ramaswamy et al., 2001; Takemura et al., 2002). Thanks to the advent of global satellite retrieved aerosol products (King et al., 1999; Kauffman et al., 2002) in combination with increasing number of ground aerosol observation stations (Holben et al., 1998), modeling studies are starting to use observational data to constrain model

Published by Copernicus Publications on behalf of the European Geosciences Union. 


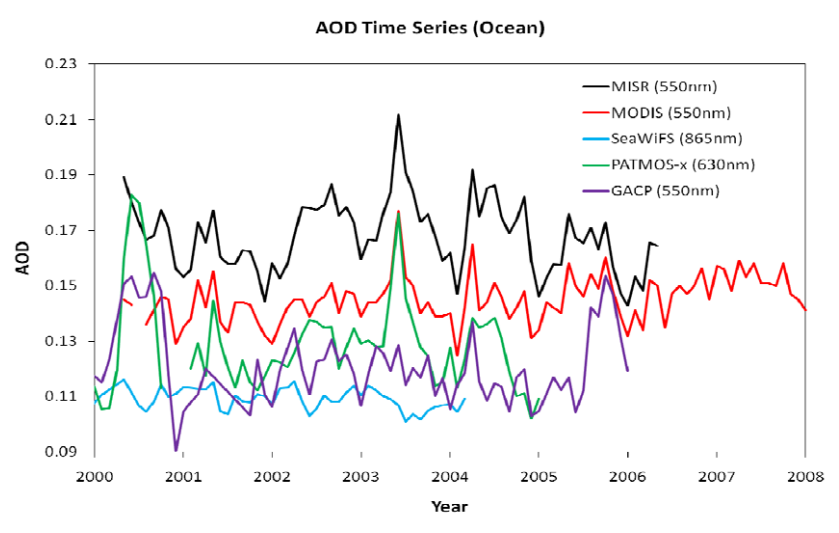

Fig. 1. Comparison of global mean AOD over ocean derived from different satellite input data and retrieval algorithms for an overlapping period since 2000. Different retrieval algorithms assuming different aerosol models (some even retrieve aerosol model such as MODIS algorithm). Converting AOD from retrieval channels to the standard $550 \mathrm{~nm}$ wavelength depend on the aerosol model used or retrieved and the extrapolation may introducing extra errors, especially for the algorithm using fixed aerosol model (such as AVHRR). Thus, we decide to display the AOD in the retrieval channel instead of extrapolating to the standard wavelength $550 \mathrm{~nm}$.

uncertainties. However, large discrepancies still exist in the estimates of aerosol direct forcing among some modeling studies (Bellouin et al., 2005; Chung et al., 2005; Yu et al., 2006; Zhao et al., 2008a) using satellite products generated from different sensors by different retrieval algorithms.

As a measure of aerosol loading, aerosol optical depth (AOD) is a basic optical property derived from many earth observation satellites (AVHRR, MODIS, MISR, TOMS/OMI, SeaWiFS, etc.) spanning from late 1970s to the present. While several inter-comparison studies (King et al., 1999; Lee et al., 2009) were conducted and some insights were gained on the causes of the discrepancies (Jeong et al., 2005; Jeong and Li, 2005; Zhao et al., 2005a, b; Kahn et al., 2007; Kokhanovsky et al., 2007; Mishchenko et al., 2007a, 2009; Liu and Mishchenko, 2008), progress has been slow to reconcile the differences and to generate integrated products so that advantages of individual products are retained while their weaknesses are circumvented or relieved (Kinne et al., 2006, 2009).

This has posed the greatest challenge to user communities in choosing an aerosol product from a rich inventory. In addition to the usage for modeling studies, the integrated product should provide a seamless long-term time series to monitor any trend changes due to natural or anthropogenic causes (Mishchenko et al., 2007b). Since more aerosol products will be generated from new sensors (e.g., CALIPSO, PARASOL, OMPS, APS, and VIIRS), the issue of consistency is becoming even more acute. This is demonstrated in Fig. 1 showing a comparison of time series of global mean AOD over ocean computed from several prominent aerosol products using dif- ferent input datasets and algorithms over the same period in recent years. Differences appear both in terms of magnitude and temporal tendency. The overall range of discrepancy amounts to about $50 \%$ of the mean AOD.

The factors involved include differences in cloud masking, treatment of surface boundary conditions, assumptions about component aerosol microphysical properties, and instrument calibration, as discussed below and in the references cited. Spurious trends may result from deficient retrieval algorithms and/or erroneous calibration of the input data (Zhao et al., 2008b). Improper assumptions used in the algorithm regarding such key parameters as aerosol type and size distribution may lead to a spurious AOD long-term trend in the regions under heavy influence of industrial and biomass burning pollutions and desert particles due to the regional biases. Consistent calibration is an even more acute problem in studying the trend of AOD using historical poorly calibrated satellite radiance data. The sign of AOD long-term trend can be reversed due to inadequate calibration (Zhao et al., 2008b).

However, sampling differences among the instruments also make major contributions to the apparent discrepancies in regional episodic events (Ignatov et al., 2005; Kahn et al., 2007). Given AOD spatial and temporal variability, convolved with actual satellite measurement frequency, the assumption that "monthly mean" data sets from these instruments can be treated as statistical representations of regional or global AOD must be examined more closely, especially for the instruments with low revisit frequency (such as MISR). This of course has implications for the way these data sets can be used for assessing long-term trends. Therefore, before the physical causes of any trends in AOD are identified, we must gain deep insights in the retrieval algorithms and input datasets, as well as data sampling, to assure they do not cause any significant artifacts of both temporal and spatial footprints in the retrieval products.

\section{Overview of long-term global AOD products}

Aerosol products have been retrieved from the AVHRR, TOMS/OMI, SeaWiFS, MODIS, and MISR for a relatively long time period. Historical aerosol products were derived from AVHRR and TOMS measurements that have the longest records of over 25 years. Since aerosol remote sensing was not included in the original instrument design, the aerosol retrievals from these traditional instruments are subject to more limitations than the retrievals from SeaWiFS, MODIS, and MISR. However, their long duration make them uniquely suited for climate studies.

\subsection{TOMS product}

This dataset was generated from the satellite observations made by NASA's Total Ozone Mapping Spectrometer 


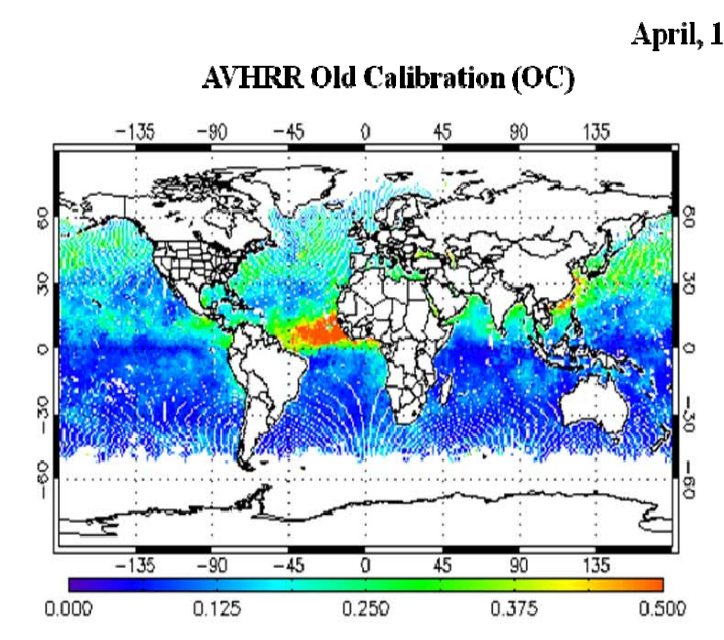

April, 1985

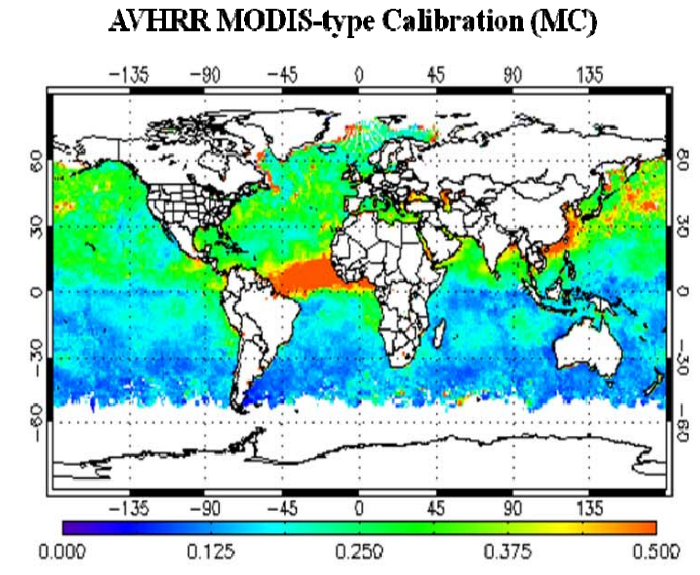

Fig. 2. Monthly mean maps of AOD at $0.63 \mu \mathrm{m}$ for April 1985 derived from old AVHRR radiances (left panel) and retrospectively calibrated AVHRR radiances using MODIS radiances (right panel).

(TOMS) sensors onboard the Nimbus-7 (1979-1992), Meteor-3 (1991-1994), ADEOS (1996-1997), Earth Probe (1996-2000) satellites. Because of the low near-UV surface albedo of all terrestrial surfaces (including deserts) except for ice or snow, the TOMS near-UV measurements from all platforms have been used to detect aerosols and retrieve their AOD and single scattering albedo (SSA) over both oceans and continents (Torres et al., 1998, 2002). The AOD has been validated through comparisons with surface Aerosol Robotic Network (AERONET) measurements. Gridded monthly mean AODs at a $1^{\circ} \times 1^{\circ}$ resolution from 1979 through 2000 are available for our study. The current TOMS aerosol algorithm (version 2) has undergone important upgrades that reduced significantly the overestimation (observed in Fig. 3) over the oceans of the version 1 record with respect to other satellite data sets.

\subsection{GACP-AVHRR aerosol data}

This dataset is the product of the NASA Global Aerosol Climate Project (GACP) established in 1998. The aerosol retrieval algorithm is based on channel-1 $(0.63 \mu \mathrm{m})$ and channel-2 $(0.85 \mu \mathrm{m})$ AVHRR observations over the oceans (Mishchenko et al., 1999; Geogdzhayev et al., 2002) and applied to the ISCCP DX radiance dataset (Rossow and Schiffer, 1999). The algorithm simultaneously retrieves the AOD and Ångström exponent (AE). Extensive studies on the accuracy of the product have been performed against shipborne measurements and SAGE, MODIS and MISR observations (Mishchenko et al., 2003, 2007a; Liu et al., 2004; Geogdzhayev et al., 2004; Smirnov et al., 2006). The monthly averaged values of AOD (at $0.55 \mu \mathrm{m}$ ) and AE are gridded at a $1^{\circ} \times 1^{\circ}$ resolution to form final global aerosol climatology over the oceans for the period of July 1983 to the present (Mishchenko et al., 2007c).

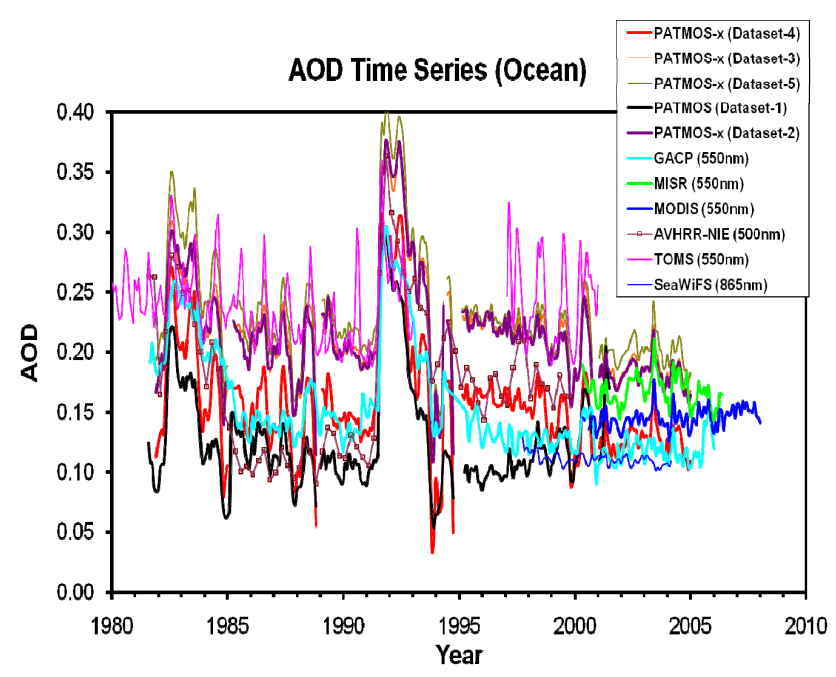

Fig. 3. Comparison of global mean AOD computed from five versions of PATMOS experimental products, with reference to the other aerosol products discussed in the paper.

Jeong and $\mathrm{Li}$ (2005) conducted an inter-comparison study between the TOMS and GACP AOD products. The general trends of the two products are similar, but their magnitudes differ beyond the differences caused by the spectral dependence of AOD due to the use of different channels (UV and visible). The two aerosol products also exhibit a good synergy. Taking advantage of their respective strengths, an algorithm was developed to classify aerosol types into dust, biomass burning, a mixture of the two, sulfate/pollution, and sea-salt. Using this algorithm, regions under the dominant influence of various types of aerosols were determined from the two satellite products, which helped convert the TOMS AOD at the UV wavelength to AOD at the visible wavelength. 
However, the causes for their differences cannot be gleaned from the use of the two monthly mean products. This initial synergy exercise on the two products will benefit the future synergy effort by including more satellite aerosol products.

\subsection{PATMOS-AVHRR data}

An early version of this AOD dataset was generated from AVHRR Pathfinder Atmosphere (PATMOS) climate dataset over oceans from September 1981 to December 2000 at 110$\mathrm{km}$ equal area global grids (Stowe et al., 2002) using a onechannel at $0.63 \mu \mathrm{m}$ algorithm (Stowe et al., 1997). The performance of the aerosol retrievals has been thoroughly evaluated against surface measurements (Stowe et al., 2002; Zhao et al., 2002) and against the MODIS product (Zhao et al., 2005a, b). The more accurate MODIS radiances were then used to re-calibrate the AVHRR radiance (Heidinger et al., 2002) by using simultaneous nadir overpass (SNO) data (Cao et al., 2004). An independent two-channel algorithm is applied to the recalibrated AVHRR radiances, leading to a new product named PATMOS-x. Better dust detection algorithm has also been developed to improve the distinction between thick dust storms and clouds (Evan et al., 2006). A consistent inter-satellite calibration using MODIS as the reference was applied to all the AVHRR sensors on different satellite platforms. As a result, the calibration accuracy of AVHRR is now compatible to that of MODIS, which is proven to be critical for determining AOD long-term trend from historical AVHRR observations (Zhao et al., 2008b).

\subsection{MODIS product}

MODIS AOD is retrieved using multiple channels from the MODIS sensors aboard the Terra and Aqua satellites, beginning in 2000 and 2002, respectively, using separate algorithms over oceans (Tanré et al., 1997) and land (Kaufman et al., 1997; Remer et al., 2005). The algorithms are continuously evaluated and periodically updated (Levy et al., 2007a, b; Remer et al., 2008). Over land, the new collection 5 eliminates the systematic overestimation of AOD for low aerosol loadings and underestimation for high loadings (Levy et al., 2007a; Li et al., 2007; Mi et al., 2007), which existed in previous collections (Chu et al., 2002; Remer et al., 2005; Levy et al., 2005). Collection 5 also expands MODIS AOD coverage to bright desert surfaces by using the deep-blue retrieval algorithm (Hsu et al., 2006). Over oceans, the MODIS AOD is systematically higher than that from the GACP aerosol product (Geogdzhayev et al., 2004). Larger regional differences between the two products are likely associated with cloud screening and the selection of aerosol size distribution models (Jeong et al., 2005; Zhao et al., 2005a, b).

\subsection{MISR product}

MISR is another important specialized instrument onboard the Terra satellite providing AOD data over oceans (Mar- tonchik et al., 1998; Kahn et al., 2001) and land (Martonchik et al., 1998; Diner et al., 2005). Given its multiple angle viewing capability, aerosol retrievals can also be made over bright surfaces such as deserts. Simulated MISR radiances for mixtures containing up to three components, are tested against observed radiances for all glint-free cameras (up to nine), at each of two wavelengths over water; over land, all nine cameras and four wavelengths are included, and the algorithm makes use of surface variability. Thus, aerosol types can be determined from the MISR aerosol retrieval. The number of aerosol mixtures and components has changed several times during the refinement of the retrieval algorithm (e.g., Kahn et al., 2005). The standard algorithm now contains three-component mixtures and uses red and NIR channels (two channels) over dark water and all four channels over land. The aerosol products have been evaluated against AERONET observations (Martonchik et al., 2004; Kahn et al., 2005; Abdou et al., 2005).

\subsection{SeaWiFS aerosol product}

SeaWiFS (1997-present) is primarily for the routine global ocean color measurements and ocean bio-optical property data generation, which requires a high accuracy in calibration and high spectral band signal-to-noise characteristics (Gordon and Wang, 1994). The SeaWiFS aerosol retrieval algorithm uses two NIR bands (765 and $865 \mathrm{~nm}$ ) to estimate the aerosol optical properties (Gordon and Wang, 1994a; Wang et al., 2005). Over productive ocean waters, bio-optical models are used to account for the NIR ocean contributions (Siegel et al., 2000; Stumpf et al., 2003). SeaWiFS routinely produces AOD at $865 \mathrm{~nm}$ and Ångström exponent products in the global oceans. The SeaWiFS AOD data have been validated against ground-based measurements (Wang et al., 2005) and used for studying aerosol effects over oceans (e.g., Chou et al., 2002). The same algorithm (Gordon and Wang, 1994a; Gordon, 1997) has been also employed to routinely derive the MODIS ocean color aerosol products (AOD and Ångström exponent) over global oceans.

The products described above have their strengths and weaknesses as summarized in Table 1 . Some of these datasets have been employed in model simulations of the global impact of aerosols on the earth's climate, while others have used them to study the trend of aerosol loading especially in the context of environmental changes. Discrepancies existing between the products must be minimized to the best of our knowledge, and ways must be found to deal with sampling limitations. In the following section, we attempt to elaborate some major potential sources that have contributed to the discrepancies. 
Table 1. Summary of the calibration approach, accuracy, and precision of existing satellite aerosol instruments.

\begin{tabular}{|c|c|c|}
\hline Instrument & Method & Reference source \\
\hline AVHRR-GACP & $\begin{array}{l}\text { Pre-launch, ISCCP post-launch using deep convective } \\
\text { clouds (absolute accuracy } \sim 5 \% \text {, to be calibrated against } \\
\text { MISR/MODIS, } \sim 1 \% \text { precision) }\end{array}$ & Rossow and Sciffer (1999) \\
\hline AVHRR-PATMOS & $\begin{array}{l}\text { Vicarious, Intersatellite (accuracy } \sim 3-5 \% \text { absolute, } \\
\text { precision } \sim 1 \% \text { ) }\end{array}$ & $\begin{array}{l}\text { Libyan desert \& SNOs } \\
\text { (Heidinger et al., 2002) }\end{array}$ \\
\hline TOMS & Vicarious $(\sim 2 \%$ accuracy $)$ & Ice and Clouds \\
\hline MISR & $\begin{array}{l}\text { On-board, vicarious, lunar }(\sim 3 \% \text { absolute; } 1-2 \% \\
\text { channel-to-channel relative; } 1 \% \text { precision })\end{array}$ & $\begin{array}{l}\text { Kahn et al. (2005b) } \\
\text { Bruegge et al. (2006) }\end{array}$ \\
\hline MODIS & $\begin{array}{l}\text { On-board, vicarious, lunar ( } \sim 2 \% \text { absolute, } \sim 1 \% \text { preci- } \\
\text { sion) }\end{array}$ & Solar diffuser \\
\hline SeaWiFS/MODIS ocean & $\begin{array}{l}\text { On-board, Vicarious, Lunar, comparison with in situ } \\
\text { (accuracy } 0.5 \% \text {; precision } \sim 0.3 \% \text { ) }\end{array}$ & $\begin{array}{l}\text { Solar, Lunar, \& Vicarious } \\
\text { over clear oceans }\end{array}$ \\
\hline
\end{tabular}

Table 2. Summary of cloud screening schemes for the satellite aerosol retrievals.

\begin{tabular}{|c|c|c|}
\hline Instrument & Method & Note \\
\hline AVHRR-GACP & $\begin{array}{l}\text { Modified ISCCP cloud detection scheme based on the } \\
\text { thermal IR channels }\end{array}$ & Mishchenko et al. (1999) \\
\hline AVHRR-NIES & Thresholds of Ch-1 reflectance and Ch-4 BT & Higurashi et al. (2000) \\
\hline AVHRR-PATMOS & CLAVR \& CLAVR-x & $\begin{array}{l}\text { Stowe et al. (1999) \& } \\
\text { Heidinger et al. (2004) }\end{array}$ \\
\hline TOMS/OMI & $\begin{array}{l}\text { Threshold of } 0.36 \mu \mathrm{m} \text { reflectance }+ \text { TOMS AI informa- } \\
\text { tion }\end{array}$ & Torres et al. (2002) \\
\hline MISR & $\begin{array}{l}\text { Multi-angle-based: radiative camera-to-camera \& } \\
\text { stereo-derived cloud masks + angular smoothness and } \\
\text { spatial correlation tests. }\end{array}$ & $\begin{array}{l}\text { DiGirolamo and Wilson (2003); } \\
\text { Martonchik et al. (2002); } \\
\text { Diner et al. (2006) }\end{array}$ \\
\hline MODIS & $\begin{array}{l}\text { Spatial variability at } 0.67 \mu \mathrm{m} \text { over ocean, } 0.46 \& 1.38 \\
\text { over land; IR } 1.38 \mu \mathrm{m} \text { test for cirrus. }\end{array}$ & $\begin{array}{l}\text { Martins et al. (2002) } \\
\text { Remer et al. (2005) }\end{array}$ \\
\hline SeaWiFS/MODIS & Threshold of $0.863 \mu \mathrm{m}$ reflectance & $\begin{array}{l}\text { Robinson et al. (2003) } \\
\text { Wang et al. (2005) }\end{array}$ \\
\hline
\end{tabular}

\section{Sources of discrepancies in AOD retrievals}

Satellite retrieval of AOD is subject to uncertainties associated with radiometric calibration, assumption of aerosol properties, cloud contamination, and correction of the surface effect. Retrieval errors stemming from these factors can diminish the retrieval quality. Temporal trends appearing in the data product, which cannot be readily identified using the traditional ground-truth and in-situ measurement, can be affected by these factors as well as by sampling limitations, time-of-day and clear-sky biases, etc.

\subsection{Calibration}

Radiance calibration is a major source of uncertainty in AOD retrievals (e.g., Higurashi and Nakajima, 1999; Ignatov and Stowe, 2002b) which could change the AOD by more than $40 \%$ (Geogdzhayev et al., 2002). Calibration method and accuracy differ considerably from sensor to sensor, as summarized in Table 1. Since the modern research sensors (e.g. MODIS and MISR) have on-board calibration systems, they are more accurate than the vicarious calibration adopted for the traditional sensors (e.g. AVHRR and TOMS).

Thus, using advanced research sensors to cross-calibrate the traditional sensors can reconcile the relatively larger uncertainties in the vicarious calibrations of the traditional sensors and reduce their uncertainties close to that of advanced research sensors. For example, the Simultaneous Nadir Overpass (SNO) method was developed specifically for intersatellite calibrations (Cao et al., 2004; Heidinger et al., 2002). More accurate MODIS reflectances ( $\pm 2 \%$ uncertainties in calibration) can be used to cross-calibrate the AVHRR reflectances ( $\pm 5 \%$ uncertainties in calibration) for the overlap operational time periods of the two instruments. The newly calibrated AVHRR radiances are applied backward 
one satellite platform each time until the last (or the earliest) platform (NOAA-9) is completed. As a result, the MODIS calibration is effectively transferred to the AVHRR instrument with uncertainties close to that of MODIS. Moreover, a consistent calibration can be applied to the AVHRR on different satellite platforms, critical for generating unbiased longterm aerosol dataset (Zhao et al., 2008b).

As an example, Fig. 2 compares AVHRR AOD retrievals using the original radiances at $0.63 \mu \mathrm{m}$ with that from the newly SNO calibrated AVHRR radiances. On a global scale, the new AODs are higher than the old AODs. Since MODIS generally has higher AOD values than the original AVHRR AOD values (e.g., Mishchenko et al., 2007a; Myhre et al., 2005; Jeong et al., 2005), the new AVHRR AODs are more consistent with those from MODIS.

Among the operational sensors, SeaWiFS achieves highest calibration accuracy ( $0.5 \%$ accuracy and $0.3 \%$ stability) through on-board, lunar (Barnes et al., 2001), and vicarious calibrations (Gordon, 1998; Eplee et al., 2001), which may also be used as the baseline reference for calibrating other sensors at cross-over instances. The SeaWiFS and MODIS (ocean color) vicarious calibrations have been carried out using the in situ data from the Marine Optical Buoy (MOBY) deployed in the west of Lanai, Hawaii (1997-present) (Clark et al., 1997).

\subsection{Cloud screening}

Arguably, the largest source of uncertainties in AOD retrievals is cloud screening (Mishchenko et al., 1999; Ignatov and Nalli, 2002; Zhao et al., 2003; Myhre et al., 2004; Jeong and Li, 2005; Jeong et al., 2005; Kaufman et al., 2005). Much attention was paid to this issue by all major AOD data producers. For the GACP product, in addition to the ISCCP cloud detection algorithm (Rossow and Garder, 1993), more conservative cloud screening algorithm was applied by Mishchenko et al. (1999) and Geogdzhayev et al. (2002). This additional cloud screening aims to eliminate small cumulus clouds and optically thin cirrus clouds. On the other hand, strict cloud masking could have the adverse effect of discarding strong aerosol signals (Husar et al., 1997; Haywood et al., 2001), which might be a major contributing factor to the systematically lower AODs from GACP compared to the MODIS product (Jeong et al., 2005). The MODIS AOD product was generated using an aerosol cloud screening method specifically developed for aerosol remote sensing (Martins et al., 2002) rather than using the nominal MODIS cloud identification scheme (Ackerman et al., 1998). SeaWiFS used the Rayleigh-corrected reflectance threshold at the NIR $(865 \mathrm{~nm})$ for the cloud discrimination (Robinson et al., 2003; Wang et al., 2005). The cloud screening schemes used by the satellite aerosol retrievals discussed in this paper are summarized in Table 2. Sensitivity studies of aerosol products (especially global monthly means) to the different cloud screening methods are lacking in all satellite aerosol products discussed here, which is a significant obstacle for reconciling the differences among the AOD datasets and needs to be resolved before a consistent and integrated satellite aerosol data product can be generated and provided to user communities.

\subsection{Selection of aerosol models}

Due to a general lack of information about aerosol types on a global scale, different aerosol models were adopted in generating the AOD products. The MODIS ocean retrieval algorithm employs 20 combinations of aerosol size distributions given by bi-log-normal (BL) functions with variable refractive indices. There are no arbitrary restrictions imposed on the retrieval choice of the 20 combinations. Over land, the MODIS algorithm specifies two aerosol models for each location and season. The GACP/AVHRR algorithm uses a modified power law size distribution with varying slope and a fixed particle refractive index. Model simulations were conducted to investigate the impact of the differences in the size distribution function and the refractive index on the AOD discrepancies (Mishchenko et al., 1999; Jeong et al., 2005). It was found that the difference in the size distribution function can create substantial AOD discrepancies of up to a factor of 2 , while different refractive indices cause a moderate systematic difference. The same finding may apply to other AOD products.

Table 3 summarizes the aerosol models used for the retrievals discussed here. Sensitivity study of influence of aerosol model selection on the AOD long-term trend performed for the AVHRR type AOD retrieval with fixed aerosol model (Zhao et al., 2008b) indicates that improper selection of aerosol model may generate spurious AOD long-term trend on the regional scale. For MISR, both statistical and case-by-case analyses of the aerosol type assumption impacts on retrieved AOD have been performed for globally distributed aerosol types (Kahn et al., 2005), spherical absorbing and non-absorbing particles (Chen et al., 2008; Kahn et al., 2007), and desert dust (Kalashnikova and Kahn, 2006). In conclusion, attention should be paid to aerosol size distributions in addition to refractive indices and cloud screening.

\subsection{Surface effect}

Except for the multi-angle technique adopted in the MISR and the UV-technique used in TOMS, removal of the surface effect, especially for relatively bright surfaces such as arid and semi-arid land and desert, is a key to the estimation of AOD from satellite observations. It is a much easier task over oceans than over land. In the MODIS and GACP algorithms, the ocean surface boundary condition is based on Cox and Munk (1954) with the wind speed set to 6 or $7 \mathrm{~m} / \mathrm{s}$ (Mishchenko and Geogdzhayev, 2007; Levy et al., 2003). SeaWiFS also implemented a surface whitecap reflectance correction algorithm (Gordon and Wang, 1994b; 
Table 3. Summary of aerosol models and instrument channels and angles used for satellite aerosol retrievals.

\begin{tabular}{|c|c|c|}
\hline Instrument & Aerosol model & Channels used \\
\hline AVHRR-GACP & Modified power - law, $n=1.5-0.003 \mathrm{i}$ & Dependent 2-Chs \\
\hline AVHRR-NIES & Bi-modal Log-N, $n=1.5-0.005 \mathrm{i}$ & Dependent 2-Chs \\
\hline AVHRR-PATMOS & Bi-modal Log-N, $n=1.45-0.003 \mathrm{i} \& 1.45-0.007 \mathrm{i}$ & Independent 2-Chs \\
\hline TOMS & $\begin{array}{l}\text { Bimodal Log-N, } 3 \text { Types, } 21 \text { aerosol models based on } \\
\text { AERONET statistics }\end{array}$ & $\begin{array}{l}\text { 2-Chs }(331,360 \mathrm{~nm}) \\
\text { Report at } 380 \mathrm{~nm} \& 500 \mathrm{~nm}\end{array}$ \\
\hline MISR & $\begin{array}{l}\text { Log-N; mixtures containing up to } 3 \text { of } 8 \text { components, in- } \\
\text { cluding non-spherical dust }\end{array}$ & $\begin{array}{l}\text { 9-angles } x \\
2 \text { spectral Chs over water }(672 \text {, } \\
867 \mathrm{~nm}) \text {; } \\
\text { 4-Chs over land }\end{array}$ \\
\hline MODIS ocean & $\begin{array}{l}\text { Bi-modal Log-N, } 4 \text { fine modes \& } 5 \text { coarse modes. } \\
\mathrm{nr}=1.36-1.53, \mathrm{ni}=0-0.005\end{array}$ & 6 channels (ocean) \\
\hline MODIS land & $\begin{array}{l}\text { Mixture of fine-dominated multi-modal Log-N with coarse- } \\
\text { dominated multi-modal Log-N at each location; } 3 \text { different } \\
\text { fine-dominated models selected a priori dependent on loca- } \\
\text { tion and season }\end{array}$ & 3-Chs (land) \\
\hline SeaWiFS/MODIS & Bi-modal Log-N, SSA from $0.93-1.0$ at $865 \mathrm{~nm}$ & $\begin{array}{l}2-\mathrm{Chs} \quad(765, \quad 865 \mathrm{~nm}) /(748, \\
869 \mathrm{~nm})\end{array}$ \\
\hline
\end{tabular}

Frouin et al., 1996) using the wind speed data. Therefore, not only is the ocean surface dark, discrepancies caused by the treatment of its effect are minimized. However, for some rough ocean surfaces, such as those in the "roaring 40s" band $\left(40^{\circ} \mathrm{S}-60^{\circ} \mathrm{S}\right)$, surface contamination may become prominent (Mishchenko and Geogdzhayev, 2007). Large differences in aerosol products, especially for aerosol Angstrom Exponent (AE), are observed from MODIS and AVHRR data collected over this region of the southern ocean (Zhao et al., 2005b).

It is generally difficult to accurately derive aerosol optical properties in the coastal ocean regions. As a result, many AOD products show discontinuity along the coastal regions (e.g., Mishchenko et al., 2009). A main challenge lies in complex turbid waters caused by river inputs, sediment resuspension or large phytoplankton blooms. For productive ocean waters, there are very significant ocean contributions at the NIR bands (Siegel et al., 2000; Stumpf et al., 2003; Wang and Shi, 2005, 2007). The ocean radiance contributions are even larger at the red bands. Thus, in the coastal regions where waters are often turbid, the satellite-derived AOD is usually over-estimated without properly accounting for the ocean contributions. In addition, a recent study (Wang, 2006) shows that in the coastal region the aerosol polarization effects may need to be included.

More efforts are called for to cope with the surface effect over land. While the spectral variation of surface albedo was taken into account in the MODIS algorithm, little has been done to account for the influence of the bidirectional reflectance distribution function (BRDF) (Luo et al., 2005). Little is known about the effect of land use and land cover change on the aerosol long-term trend. Table 4 lists the ma- jor features of the surface treatment for the major aerosol retrieval algorithms discussed here.

Since historical AVHRR, current EOS/MODIS, and future NPOESS/VIIRS instruments are more comparable than the other instruments involved and can eventually cover a time period of about 50 years together, more effort should be put on the comparison and reconciliation of these products. AOD and the Angstrom exponent (AE) should be treated as two core products since they are available from almost all the instruments. Spherical vs. non-spherical particle type distinctions are produced for AOD $>\sim 0.15$ or 0.2 by MISR. Fine/coarse fraction modes, SSA, and any other aerosol optical properties are highly desired but are formidable to achieve at present. A consistent long-term AOD and AE products with sufficient climate application quality using AVHRR and MODIS measurement as the kernel and the measurement from other historical, current, and future satellite instrument as supplement could be generated eventually through data synergy.

\section{Demonstration of the impact of retrieval uncertain- ties on global AOD products, aerosol radiative forc- ing, their temporal variations}

To comprehend the large discrepancies exhibited in Fig. 1 in the context of various potential contributing factors as described above, tests were conducted by applying different retrieval algorithms to the PATMOS and PATMOS-x aerosol products (Stowe et al., 2002; Zhao et al., 2008b) spanning nearly 25 years from September 1981 to December 2004. Five datasets are generated as outlined in Table 5. 
Table 4. Summary of surface treatment for the major aerosol retrieval algorithms.

\begin{tabular}{|c|c|c|}
\hline Instrument & Method & Note \\
\hline AVHRR-GACP & $\begin{array}{l}\mathrm{Bi} \text { - directional (Cox-Munk with variable } \\
\text { wind speed taken from assimilation) }\end{array}$ & + small Lambertian component \\
\hline AVHRR-NIES & $\begin{array}{l}\text { Bi- directional (modified Cox-Munk) with } \\
\text { variable wind speed taken from NCEP re- } \\
\text { analysis }\end{array}$ & + small Lambertian component \\
\hline AVHRR-PATMOS & $\begin{array}{l}\text { Bi- directional (Cox-Munk) with fixed } \\
\text { wind speed }\end{array}$ & + small Lambertian component \\
\hline TOMS & $\begin{array}{l}\text { Aerosol-corrected TOMS climatology of } \\
\text { minimum lambertian reflectance }\end{array}$ & \\
\hline MISR & $\begin{array}{l}\text { Bi-Directional } \\
\text { (Cox-Munk + whitecap over Ocean param- } \\
\text { eterized as function of wind speed; } \\
\text { Spectrally invariant surface angular shapes } \\
\text { plus empirically derived bidirectional re- } \\
\text { flectances from the data) }\end{array}$ & $\begin{array}{l}\text { Lambertian spectral water-leaving re- } \\
\text { flectance retrieval being developed }\end{array}$ \\
\hline MODIS & $\begin{array}{l}\text { Bi- directional (Cox-Munk) - Ocean } \\
\text { Dark Pixel - Land assuming spectral ratios }\end{array}$ & + small Lambertian component over ocean \\
\hline SeaWiFS/MODIS & $\begin{array}{l}\mathrm{Bi} \text { - directional (Cox-Munk) + whitecaps } \\
\text { driven by wind speed }\end{array}$ & + correction on visible and $765 \& 865 \mathrm{~nm}$ \\
\hline
\end{tabular}

Table 5. Five long term aerosol datasets from the AVHRR observations used in the current AOD tendency analysis. $\tau_{1}$ and $\tau_{2}$ are AOD of AVHRR Channel $1(0.63 \mu \mathrm{m})$ and $2(0.83 \mu \mathrm{m})$, respectively.

\begin{tabular}{cccccc}
\hline Datasets & Products & Retrieval resolution & Time coverage & Algorithm & Notes \\
\hline 1 & $\tau_{1}$ & Pixel level (GAC data) & $1981-2001$ & One-channel & PATMOS, Old Calibration \\
2 & $\tau_{1}$ and $\tau_{2}$ & Pixel level $($ GAC data) & $1981-2004$ & Two-channel & PATMOS-x, New Calibration \\
3 & $\tau_{1}$ and $\tau_{2}$ & Grid level $\left(0.5^{\circ} \times 0.5^{\circ}\right)$ & $1981-2004$ & Two-channel & PATMOS-x based, New Calibration \\
4 & $\tau_{1}$ and $\tau_{2}$ & Grid level $\left(0.5^{\circ} \times 0.5^{\circ}\right)$ & $1981-2004$ & Revised Two-channel & PATMOS-x based, New Calibration \\
5 & $\tau_{1}$ & Grid level $\left(0.5^{\circ} \times 0.5^{\circ}\right)$ & $1981-2004$ & One-channel & PATMOS-x based, New Calibration \\
\hline
\end{tabular}

Dataset 1 gives AOD at $0.63 \mu \mathrm{m}$ using the single-channel algorithm of Stowe et al. (1997) with the original vicarious calibration from Libyan deserts. The more accurate MODIS radiances were used to re-calibrate the AVHRR radiance retrospectively (Heidinger et al., 2002) to produce a new product, which is named as PATMOS-X and has been extended to 2005 by including the AVHRR observations from the NOAA-15, -16 , and -17 . The dataset 2 of PATMOS-x is derived from the pixel-level daily orbital radiances sampled from the AVHRR Global Area Coverage (GAC) data and in a spatial resolution of $8 \mathrm{~km} \times 8 \mathrm{~km}$ using two-channel algorithm of Ignatov and Stowe (2002a). It provides AOD in the AVHRR channel $1(0.63 \mu \mathrm{m}), \tau_{1}$, and channel $2(0.83 \mu \mathrm{m})$, $\tau_{2}$. It assumes an aerosol model of non-absorbing with onemode log-normal size distribution over ocean surface under the wind speed of $1 \mathrm{~m} / \mathrm{s}$ for the calculation of ocean surface reflectance. Dataset 3 is the same as dataset 2 except for a degraded resolution of $0.5^{\circ} \times 0.5^{\circ}$. Comparing these two datasets, one notices rather small differences, so that we can use the course resolution data to perform the tests more efficiently. Dataset 4 is generated using a revised two-channel algorithm that led to the best agreements with ground-based observations (Zhao et al., 2004), due to the use of a more realistic aerosol model (weak-absorbing with bi-modal lognormal size distribution) and globally averaged ocean surface wind speed $(6 \mathrm{~m} / \mathrm{s})$. Dataset 5 is similar to dataset 1 but using new SNO calibration data. All five datasets are over ocean only to avoid large uncertainties resulting from highly variable and reflective land surfaces. Apart from the strong interruptions by volcano eruptions of El Chichón in March 1982 and Mt. Pinatubo in June 1991, the long-term variation in AOD could be seen in the Fig. 3. Unfortunately, the faint signal of the inter-annual variation is overshadowed by the exceptionally large discrepancies among the various products. 
The largest systematic discrepancy is found between Dataset 1 and 5, due simply to the use of different calibrations. This is not surprising, as the AOD signal is extracted from a reflectance signal that is so faint that any change in the calibration may substantially alter the retrieval of AOD. From this finding, one may thus make a conjecture that the differences in the calibration as given in Table 1 might account for a great deal to the AOD differences shown here. As such, to make the AOD compatible, we must assure radiances measured by different sensors agree first. The SNO calibration method applied to the PATMOS-X is therefore a sound and valid approach to bring the historical AVHRR data into agreement with the MODIS. For trend detection, however, absolute calibration is less important than other factors. The same input data, however, do not necessarily lead to the same AOD retrieval. The AOD from dataset 2 differs considerably from the MODIS AOD, even though their calibrated radiances are similar. This is because of large differences in the aerosol model and treatment of surface reflectance. In narrowing the discrepancy, Zhao et al. (2004) adopted a relatively more realistic aerosol model based on the validation with the AERONET observation. After retuning based on AERONET observations, the revised algorithm (dataset 4) leads to the AOD in close proximity with the MODIS products. This is supported by the finding of Jeong et al. (2005) showing very large differences brought by applying two distinct models of aerosol size distribution, the power law and bi-lognormal functions to the same radiance data. Ironically, not only does the dataset 4 AOD agree broadly with the MODIS AOD, it also agrees with the GACP AOD, while the latter employed the power-law size distribution, as is shown more clearly in Fig. 4. Such a level of consistency in AOD is unprecedented, even though regional discrepancies may still be much larger. Yet there is still disagreement in the tendency over the short overlapping period (see Fig. 1) from weak positive (MODIS) to weak negative (GACP, PATMOX-x, SeaWiFS, and MISR), which we think is due to the differences in the cloud screening schemes and warrants a more detailed investigation.

Despite of the good agreement, we are still confronted with fundamental challenges in choosing the right aerosol models characterized by both the size distribution and absorbing property. Lack of constraints on both key variables could produce spurious long-term trends. Note that AOD is just one of the three basic variables to determine their radiative effects. For the same AOD but different SSA and asymmetry factor (also surface albedo), the implied radiative forcing can change in magnitude or even in sign. Unfortunately, both aerosol particle size distribution and SSA are hard to quantify. To date, their measurements are limited to a handful of field experiments that reveal strong variation with time and location. At present, instruments specialized in measuring both variables are very expensive prohibiting widespread usage. Few methods are available for application over large scales on routine basis. By virtue of the combi-

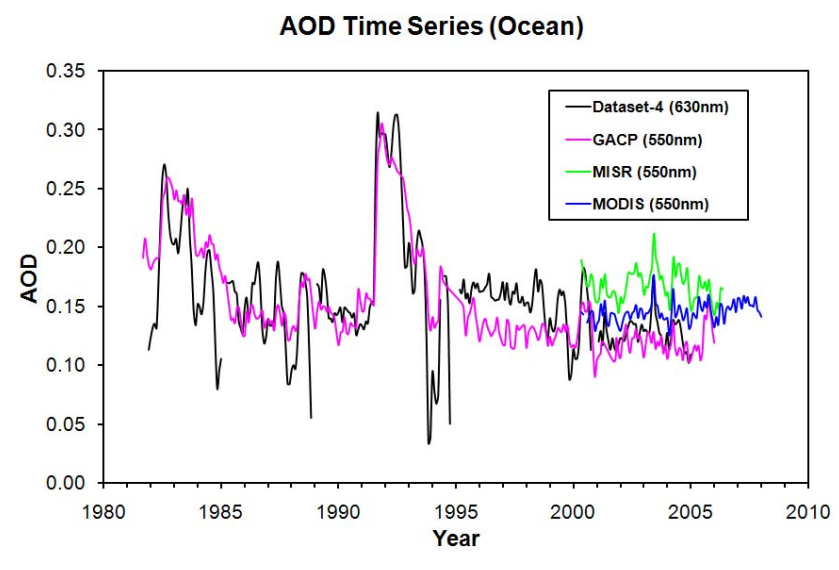

Fig. 4. Comparison of a subset of four latest AOD products.

nation of ground-based clear-sky measurements of transmittance and space-borne measurements of TOA reflectance, the approach proposed by Lee et al. (2007) has certain merit for routine determination of the SSA over large areas, but it is only valid under heavy aerosol loading conditions.

Before radical advances occur to physically characterize aerosols, a feasible means of improving the AOD retrieval appears to be the traditional approach of analyzing retrieval results in light of near-coincident ground-based and aircraft observations. To a certain extent, the good agreement shown here is attributed to extensive validations against the same ground-based observations, primarily the global AERONET (Holben et al., 1998) data. Data from this network provide globally distributed and quality controlled observations and inferences of aerosol spectral optical depth, aerosol size distribution and refractive index (Dubovik and King, 2000; Holben et al., 2001; Smirnov et al., 2002b, 2003; Dubovik et al., 2002). There are currently over 200 AERONET sites in operation of variable durations. AERONET measurements have been employed to validate the retrievals of AOD from the AVHRR (e.g., Higurashi et al., 2000; Zhao et al., 2002, 2003), TOMS/OMPS (e.g., Hsu et al., 1999; Torres et al., 2002), MODIS (e.g. Chu et al., 2002; Ichoku et al., 2002, 2003, 2005; Remer et al., 2002, 2005), and MISR (e.g., Diner et al., 2001; Martonchik et al., 2004; Abdou et al., 2005; Kahn et al., 2005a, b, 2007; Kalashnikova and Kahn, 2006; Chen et al., 2008). However, further evaluation in the context of performance matrix could be beneficial, including additional scatter plots, PDF, long-term time series, consistent checks, and dependent checks (on the calibration, aerosol model selection, cloud screening, and surface treatment) for both episodic scenarios and long-term time series.

To put the AOD discrepancies in the context of solar aerosol direct radiative effect (ADRE), we used the mean and standard deviation of aerosol optical properties derived from 436 AERONET stations around the world (SSA of 0.92 and asymmetry factor of 0.69 ) to compute ADRE at the top, 


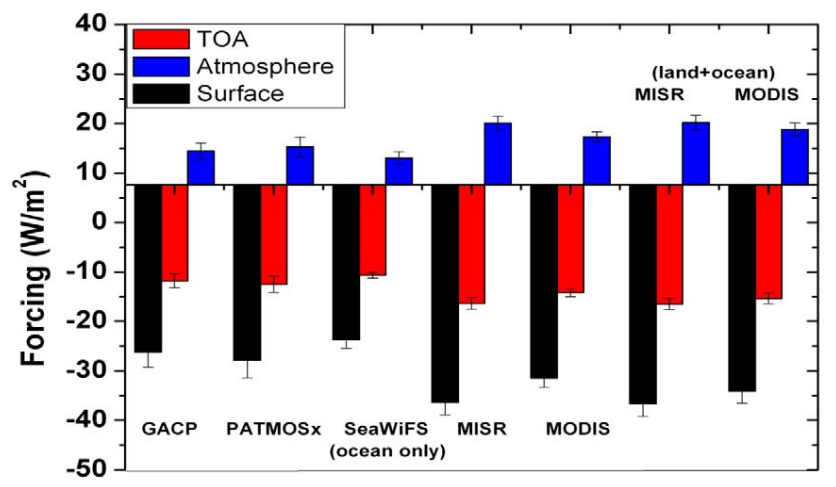

Fig. 5. Aerosol radiative forcing at the top, bottom and inside of the atmosphere computed from global mean aerosol optical depths derived from various satellite sensors and global mean aerosol optical properties estimated from 436 AERONET stations for a solar zenith angle of $40^{\circ}$ and albedo of $5 \%$.

bottom and inside of the atmosphere. The radiative transfer calculations were done by assuming a mean solar zenith angle of $40^{\circ}$ and a mean surface albedo of $5 \%$ (representative of ocean and visible land surface). Figure 5 shows the ADRE for the three layers. It is seen that the means of the ADRE for different global datasets ranges from -10.6 (SeaWiFS) to $-16.3 \mathrm{~W} \mathrm{~m}^{-2}$ (MISR) for TOA, -23.7 to $-36.3 \mathrm{~W} \mathrm{~m}^{-2}$ at the surface, and 13 to $20 \mathrm{~W} \mathrm{~m}^{-2}$ in the atmosphere. The relative ADRE discrepancies are $46 \%, 43 \%$ and $42 \%$ for the surface, TOA and atmosphere respectively. Note that these are instantaneous values that should not be compared with the annual and daily averages as reported in many other studies as summarized in Yu et al. (2006). Dividing the values displayed here by a factor of 2 are approximate estimates of the daily mean values (Zhang et al., 2005b). However, the relative discrepancies among these values are compatible to those of Yu et al. (2006) who compiled the global means of ADRE (TOA and ocean only) estimated by various investigators using different satellite products by assuming different aerosol properties. Since we employed the same aerosol properties, the discrepancies stem from nothing but AOD. The compatible relative discrepancies thus suggest that the differences in our current estimates of the global ADRE are chiefly attributed to the discrepancies in AOD, which is most likely linked to the TOA clear-sky radiances used in different retrievals following different methods of cloud screening and calibration.

Figure 6 shows the time series of the ADRE in the three layers over the EOS era beginning in 2000. There is a tendency that the discrepancies converge in recent years, especially between the MODIS and MISR. This is probably due to adjustments of the algorithms based on recent active intercomparisons and ground truth validation performed by individual aerosol producers. However, more studies are still necessary to explain the differences in detailed variations and

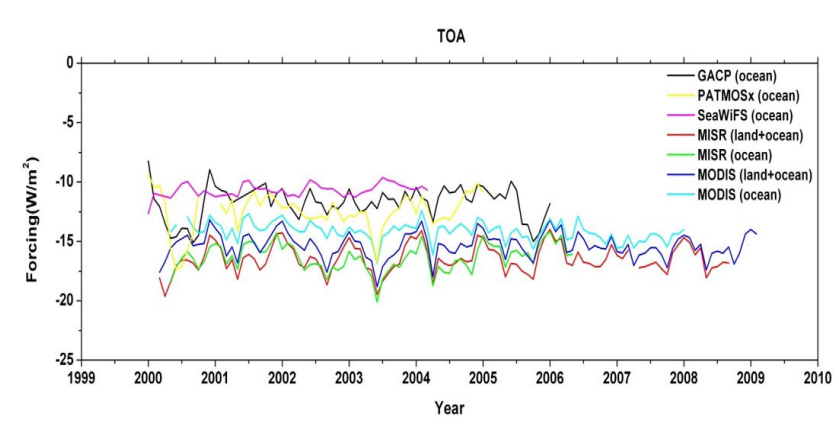

Fig. 6. Time series of the global mean aerosol radiative forcing at the top of the atmosphere based on different global aerosol optical depth products of the same aerosol optical properties from AERONET.

to achieve consistent long-term AOD trends (both global and regional) from various instruments.

\section{Concluding remarks and recommendations}

As importance of aerosols in the earth's system is recognized, the number of global aerosol products generated from space-borne sensors has dramatically increased within the last decade thanks largely to the advent of the earth observation system. Despite steady improvement in data quality, uncertainties in the retrieval of the most basic aerosol variable, AOD remain so large that can hardly be utilized to monitor the trend of its long-term variation. As a tutorial demonstration of the extent of the problem, this paper only shows some cursory comparisons of the global mean AOD values. On regional scales, the differences can be much larger and a lot more complex, as aerosol properties are so diverse that any fixed aerosol model leads to large regional biases. Even for such a highly averaged quantity, the discrepancies among different products exceed the signal of inter-annual variability, although the precision of the products is significantly better than the discrepancy (e.g., Mishchenko et al., 2007a, 2009). To make a good use of the products for both climate modeling and monitoring, we must first understand and resolve the discrepancies and then produce consistent and unified products of higher accuracy. For monitoring the long-term changes of atmospheric environments and their impact on climate change, we have to bridge historical, current, and future (e.g., Mishchenko et al., 2007d) satellite products.

Towards achieving these goals, each individual product needs to be extensively and rigorously validated and evaluated. Evaluation of the discrepancies requires detailed analysis, in addition to independent measurements, to disclose their causes, and it is difficult to obtain the "true" values of remotely sensed fields. Aerosol remote sensing is subject to four primary uncertain factors: sensor calibration, cloud screening, aerosol optical properties and surface reflectance. Sensor calibration stability is key to long-term 
monitoring. The weak radiometric signal of aerosols requires much higher calibration accuracy and precision than other space-borne remote sensing elements such as cloud. For long-term monitoring without interruption, we must maintain at least one sensor of high stability at sufficient number of channels in a polar orbit so that other sensors can be at least cross-calibrated. The biggest challenge confronted us is retrospective calibration of the weather sensors priori to the EOS era. In the EOS era, calibration appears to be a secondary problem relative to other uncertain factors.

Cloud screening is one of the largest sources of discrepancies, especially on pixel and regional scales, which is dualedge problem. The root of the problem traces to a vague bound between cloud and aerosol, at least in the "eyes" of satellite sensors, and the empirical nature of cloud screening. Over- and under-screening clouds lead to under- and over-estimate of aerosol loadings. An example is dust storm whose spectral signature is somewhat similar to clouds and as a result one may totally miss it or have some residual clouds misclassified as dust. In the era of A-train especially thanks to the two active sensors (CALIPSO and CLOUDSAT), our capability has been enhanced considerably to discriminate residual/thin clouds and thick aerosol layers. It is thus recommended for each cloud screening method designed for a particular sensor to be modified in conformity with an integrated method taking advantage of the suite of A-train sensors. For those sensors that fly in different orbits at different times, the method may be tuned to generate similar PDFs. By doing so, we can eliminate/lessen a primary source of uncertainty that contaminate the quality of aerosol products.

Aerosol absorption dictated chiefly by size distribution and composition is an inherent problem common to all sensors. For known TOA reflectance, the retrieval of AOD is very sensitive to this property, as well as its vertical distribution in the atmosphere. Advance in AOD retrieval is contingent upon the improvement in our knowledge of aerosol properties which further relies on ground-based and/or airborne measurements. In addition, for strongly absorbing aerosols, accurate satellite AOD retrievals require accurate aerosol vertical information, e.g., from CALIPSO measurements. There currently exist a handful of stations measuring many relevant aerosol attributes: light scattering and absorption coefficients, particle number concentrations, and chemical composition. Stations measuring these quantities have been operated at its baseline observatories since the mid1970s by the NOAA Climate Monitoring and Diagnostics Laboratory (CMDL) (Delene and Ogren, 2002). These surface measurements provide valuable information pertaining to the long-term changes in background aerosol properties and the influence of regional sources on aerosol optical properties' statistics and trends. Such observations are very expensive to make. Intensive short-term campaign is a sound approach to remedy the problem, which has been conducted in numerous places with different dominant aerosol types around the world. Besides, aerosol type information obtained from model simulations, such as the GOCART model (Chin et al., 2002), or classification using remote sensing data (e.g. Jeong and $\mathrm{Li}, 2005$ ) would also be helpful to reduce ambiguity. It is worth noting that different algorithms/sensors have different sensitivity. For example, MISR has more sensitivity to certain particle properties, such as shape, than other operational instruments mentioned in this paper (e.g., Kalashnikova and Kahn, 2006).

Variable and uncertain surface albedo has limited many global aerosol products to oceans only. The problem has been alleviated considerably by the multi-channel approach of MODIS (Kaufman et al., 1997; Hsu et al., 2004) and the multi-angle approach of MISR (Martonchik et al., 1998). The improved relationship between short-wavelength and long-wavelength surface reflectance adopted in the MODIS C5 algorithm (Levy et al., 2006) has significantly improved its accuracy over land (Li et al., 2007). Further improvement is possible by refining the relationship with respect to land cover types, pixel resolution and better accounting for the bidirectional reflectance distribution function (BRDF). The deep blue approach (Hsu et al., 2004) applied to MODIS observations extends MODIS AOD retrieval to over bright surfaces, but more improvements is necessary to better cope with transitional land covers.

Ultimately, we ought to generate a single most trustworthy product by integrating data from various sensors and using the best of knowledge about aerosols, as the nature only present us with one true world. Of little doubt, each sensor has its strength and weakness. An integrated aerosol product should make use of synergetic information conveyed in the all available satellite data, which have been validated through inter-comparison and ground truth validation. The integrated product is expected to be superior to any individual product. It will link historical, current, and future satellite observations for long-term trend analysis and climate studies.

Acknowledgements. This research was funded by the NASA Radiation Sciences Program (NNX08AH71G, NNH04AA26I), the NASA Glory Mission project, and NSF (IIS0611892). Additional funding support is also provided by NOAA, and the MOST (2008CB403706).

Topical Editor F. D'Andrea thanks two anonymous referees for their help in evaluating this paper.

\section{References}

Abdou, W. A., Diner, D. J., Martonchik, J. V., Bruegge, C. J., Kahn, R. A., Gaitley, B. J., Crean, K. A., Remer, L. A., and Holben, B.: Comparison of coincident Multiangle Imaging Spectroradiometer and Moderate Resolution Imaging Spectroradiometer aerosol optical depths over land and ocean scenes containing Aerosol Robotic Network sites, J. Geophys. Res., 110(D10), D10S07, doi:10.1029/2004JD004693, 11967-11976, 2005.

Ackerman, S. A., Strabala, K. I., Menzel, W. P., Frey, R. A., Moeller, C. C., and Gumley, L. E.: Discriminating clear-sky from 
clouds with MODIS, J. Geophys. Res., 103(D24), 32141-32158, 1998.

Barnes, R. A., Eplee Jr., R. E., Schmidt, G. M., Patt, F. S., and McClain, C. R.: Calibration of SeaWiFS, I: Direct techniques, Appl. Optics, 40(36), doi:10.1364/AO.40.006682, 6682-6700, 2001.

Bellouin, N. Q., Boucher, O., Haywood, J., and Reddy, M. S.: Global estimate of aerosol direct and radiative forcing from satellite measurements, Nature, 438, 1138-1141, doi:10.1038/nature04348, 2005.

Bruegge, C. J., Diner, D. J., Kahn, R. A., Chrien, N., Helmlinger, M. C., Gaitley, B. J., and Abdou, W. A.: The MISR radiometric calibration process, Rem. Sens. Environ., 107, 2-11, doi:10.1016/j.rse.2006.07.024, 2007.

Cao, C., Weinreb, M., and Xu, H.: Predicting Simultaneous Nadir Overpasses among polar-orbiting meteorological satellites for the intersatellite calibration of radiometers, J. Atmos. Oceanic Tech., 21(4), 537-542, doi:10.1175/1520-0426(2004)021, 2004.

Chen, W.-T., Kahn, R., Nelson, D., Yau, K., and Seinfeld, J.: Sensitivity of multi-angle imaging to optical and microphysical properties of biomass burning aerosols, J. Geophys. Res., 113, D10203, doi:10.1029/2007JD009414, 2008.

Chin, M., Ginoux, P., Kinne, S., Torres, O., Holben, B., Duncan, B. N., Martin, R. V., Logan, J. A., Higurashi, A., and Nakajima, T.: Tropospheric aerosol optical thickness from the GOCART model and comparisons with satellite and sunphotometer measurements, J. Atmos. Sci., 59(3), 461-483, doi:10.1175/15200469(2002)059, 2002.

Chou, M. D., Chan, P. K., and Wang, M.: Aerosol radiative forcing derived from SeaWiFS-retrieved aerosol optical properties, J. Atmos. Sci., 59(3), 748-757, doi:10.1175/1520-0469(2002)059, 2002.

Chu, D. A., Kaufman, Y. J., Ichoku, C., Remer, L. A., Tanre, D., Holben, B. N., Validation of MODIS aerosol retrieval over land, Geophys. Res. Lett., 29(12), 8008, doi:10.1029/2001GL013205, 2002.

Chung, C. E., Ramanathan, V., Kim, D., and Podgorny, I.: Global anthropogenic aerosol direct forcing deribed from satellite and ground-based observations, J. Geophys. Res., 110, D24207, doi:10.1029/2005JD006356, 2005.

Clark, D. K., Gordon, H. R., Voss, K. J., Ge, Y., Broenkow, W., and Trees, C.: Validation of atmospheric correction over the oceans, J. Geophys. Res., 102(D14), 17209-17217, 1997.

Cox, C. and Munk, W.: Statistics of the sea surface derived from sun glitter, J. Mar. Res., 13, 198-227, 1954.

Delene, D. J. and Ogren, J. A.: Variability of aerosol optical properties at four North American surface monitoring sites, J. Atmos. Sci., 59(6), 1135-1150, doi:10.1175/1520-0469(2002)059, 2002.

Di Girolamo, L. and Wilson, M. J.: A first look at banddifferenced angular signatures for cloud detection from MISR, IEEE Trans. Geosci. Remote Sens., 41(7), 1730-1734, doi:10.1109/TGRS.2003.815659, 2003.

Diner, D. J., Abdou, W. A., Conel, J. E., Crean, K. A., Gaitley, B. J., Helmlinger, M., Kahn, R. A., Martonchik, J. V., and Pilorz, S. H.: MISR aerosol retrievals over southern Africa during the SAFARI-2000 dry season campaign, Geophys. Res. Lett., 28(16), 3127-3130, 2001

Diner, D. J., Martonchik, J. V., Kahn, R. A., Pinty, B., Gobron, N., Nelson, D. L., and Holben, B. N.: Using angular and spectral shape similarity constraints to improve MISR aerosol and surface retrievals over land, Rem. Sens. Environ., 94(2), 155-171, doi:10.1016/j.rse.2004.09.009, 2005.

Diner, D. J., Abdou, W. A., Ackerman, T. P., Crean, K., Gordon, H. R., Kahn, R. A., Martonchik, J. V., Paradise, S. R., Pinty, B., Verstraete, M. M., Wang, M., and West, R. A.: Multi-angle Imaging SpectroRadiometer Level 2 Aerosol Retrieval Algorithm Theoretical Basis, Revision F. Jet Propulsion Laboratory, California Institute of Technology JPL D-11400, 2006.

Dubovik, O. and King, M. D.: A flexible inversion algorithm for retrieval of aerosol optical properties from Sun and sky radiance measurements, J. Geophys. Res., 105(D16), 20673-20696, 2000.

Dubovik, O., Holben, B. N., Eck, T. E., Smirnov, A., Kaufman, Y. J., King, M. D., Tanre, D., and Slutsker, I.: Variability of absorption and optical properties of key aerosol types observed in worldwide locations, J. Atmos. Sci., 59(3), 590-608, doi:10.1175/1520-0469(2002)059, 2002.

Eplee Jr., R. E., Robinson, W. D., Bailey, S. W., Clark, D. K., Werdell, P. J., Wang, M., Barnes, R. A., and McClain, C. R.: The calibration of SeaWiFS, Part 2: Vicarious techniques, Appl. Optics, 40(36), 6701-6718, doi:10.1364/AO.40.006701, 2001.

Evan, A. T., Heidinger, A. K., and Pavolonis, M. J.: Development of a new over-water advanced very high resolution radiometer dust detection algorithm, Int. J. Remote Sens., 27(18), 3903-3924, doi:10.1080/01431160600646359, 2006.

Frouin, R., Schwindling, M., and Deschamps, P. Y.: Spectral reflectance of sea foam in the visible and near infrared: In situ measurements and remote sensing implications, J. Geophys. Res., 101(C6), 14361-14371, 1996.

Geogdzhayev, I. V., Mishchenko, M. I., Rossow, W. B., Cairns, B., and Lacis, A. A.: Global two-channel AVHRR retrievals of aerosol properties over the ocean for the period of NOAA-9 observations and preliminary retrievals using NOAA-7 and NOAA11 data, J. Atmos. Sci., 59(3), 262-278, doi:10.1175/15200469(2002)059, 2002.

Geogdzhayev, I. V., Mishchenko, M. I., Liu, L., and Remer, L.: Global two-channel AVHRR aerosol climatology: effects of stratospheric aerosols and preliminary comparisons with MODIS and MISR retrievals, J. Quant. Spectrosc. Radiat. Transfer, 88, 47-59, 2004.

Gordon, H. R. and Wang, M.: Retrieval of water-leaving radiance and aerosol optical thickness over the oceans with SeaWiFS: A preliminary algorithm, Appl. Optics, 33(3), 443-452, doi:10.1364/AO.33.000443, 1994a.

Gordon, H. R. and Wang, M.: Influence of oceanic whitecaps on atmospheric correction of ocean-color sensor, Appl. Optics, 33(33), 7754-7763, doi:10.1364/AO.33.007754, 1994b.

Gordon, H. R.: Atmospheric correction of ocean color imagery in the Earth Observing System era, J. Geophys. Res., 102, 1708117106, 1997.

Gordon, H. R.: In-orbit calibration strategy for ocean color sensors, Rem. Sens. Environ., 63, 265-278, 1998.

Hansen, J., Sato, M., Nazarenko, L., et al.: Climate forcing in Goddard Institute for Space Studies SI2000 simulations, J. Geophys. Res., 107(D18), 4347, doi:10.1029/2001JD001143, 2002.

Haywood, J. M., Francis, P. N., Geogdzhayev, I., Mishchenko, M., and Frey, R.: Comparison of Saharan dust aerosol optical depths retrieved using aircraft mounted pyranometers and 2-channel AVHRR algorithms, Geophys. Res. Lett., 28(12), 2393-2396, 
2001.

Heidinger, A. K., Cao, C., and Sullivan, J.: Using Moderate Resolution Imaging Spectrometer (MODIS) to calibrate Advanced Very High Resolution Radiometer (AVHRR) reflectance channels, J. Geophys. Res., 107(D23), 4702, doi:10,1029/2001JD002035, 2002.

Heidinger, A. K., Goldberg, M. D., Tarpley, D., Jelenak, A., and Pavolonis, M.: A new AVHRR cloud climatology. Applications with Weather Satellites II, Honolulu, Hawaii, 9-11 November 2004. Proceedings, SPIE-The International Society for Optical Engineering, Bellingham, WA, 2005, pp. 197-205, Call Number: Reprint \# 4198, 2004.

Higurashi, A. and Nakajima, T.: Development of a two channel aerosol retrieval algorithm on global scale using NOAA/AVHRR, J. Atmos. Sci., 56(7), 924-941, doi:10.1175/1520-0469(1999)056, 1999.

Higurashi, A. and Nakajima, T., Holben, B. N., Smirnov, A., Frouin, R., Chatenet, B.: A study of global aerosol optical climatology with two-channel AVHRR remote sensing, J. Climate, 13(12), 2011-2027, doi:10.1175/1520-0442(2000)013, 2000.

Hofmann, D. J.: Twenty years of balloon-borne tropospheric aerosol measurements at Laramie, Wyoming, J. Geophys. Res., 98(D7), 12753-12766, 1993.

Holben, B. N., Eck, T. F., Slutsker, I., Tanre, D., Buis, J. P., Setzer, A., Vermote, E., Reagan, J. A., Kaufman, Y. J., Nakajima, T., Lavenu, F., Jankowiak, I., and Smirnov, A.: AERONET-A federated instrument network and data archive for aerosol characterization, Rem. Sens. Environ., 66(1), 1-16, doi:10.1016/S00344257(98)00031-5, 1998.

Holben, B. N., Tanre, D., Smirnov, A., Eck, T. F., Slutsker, I., Abuhassan, N., Newcomb, W. W., Schafer, J., Chatenet, B., Lavenue, F., Kaufman, Y. F., Van de Castle, J., Setzer, A., Markham, B., Clark, D., Frouin, R., Halthore, R., Karnelli, N. A., O'Neill, N. T., Pietras, C., Pinker, R., Voss, K., and Zibordi, G.: An emerging ground-based aerosol climatology: Aerosol optical depth from AERONET, J. Geophys. Res., 106(D11), 1206712097, 2001.

Hsu, N. C., Herman, J. R., Torres, O., Holben, B. N., Tanre, D., Eck, T. F., Smirnov, A., Chatenet, B., and Lavenu, F.: Comparisons of the TOMS aerosol index with Sun-photometer aerosol optical thickness: Results and applications, J. Geophys. Res., 104(D6), 6269-6280, 1999.

Hsu, N. C., Tsay, S.-C., King, M. D., and Herman, J. R.: Deep blue retrievals of Asian aerosol properties during ACE-Asia, Geosci. Rem. Sens., IEEE Transactions, 44(11), 3180-3195, doi:10.1109/TGRS.2006.879540, 2006.

Husar, R. B., Prospero, J. M., and Stowe, L. L.: Characterization of tropospheric aerosols over the oceans with the NOAA advanced very high resolution radiometer optical thickness operational product, J. Geophys. Res., 102(D14), 16889-16909, 1997.

Ichoku, C., Chu, D. A., Mattoo, S., Kaufman, Y. J., Remer, L. A., Tanre, D., Slutsker, I., and Holben, B. N.: A spatio-temporal approach for global validation and analysis of MODIS aerosol products, Geophys. Res. Lett., 29(12), doi:10.1029/2001GL013206, 2002.

Ichoku, C., Remer, L. A., Kaufman, Y. J., Levy, R., Chu, D. A., Tanre, D., and Holben, B. N.: MODIS observation of aerosols and estimation of aerosol radiative forcing over southern Africa during SAFARI 2000, J. Geophys. Res., 108(D13), 8499,
doi:10.1029/2002JD002366, 2003.

Ichoku, C., Remer, L. A., and Eck, T. F.: Quantitative evaluation and intercomparison of morning and afternoon MODIS aerosol measurements from Terra and Aqua, J. Geophys. Res., 110, D10S03, doi:10.1029/2004JD004987, 2005.

Ignatov, A. and Stowe, L.: Aerosol retrievals from individual AVHRR channels. Part I: Retrieval algorithm and transition from dave to $6 \mathrm{~S}$ radiative transfer model, J. Atmos. Sci., 59(3), 313334, 2002a.

Ignatov, A. and Stowe, L.: Sensitivity and information content of aerosol retrievals from AVHRR: Radiometric factors, Appl. Optics, 41(6), 991-1011, doi:10.1364/AO.41.000991, 2002b.

Ignatov, A. and Nalli, N. R.: Aerosol retrievals from the multiyear multisatellite AVHRR pathfinder atmosphere (PATMOS) dataset for correcting remotely sensed sea surface temperatures, J. Atmos. Oceanic Technol., 19(12), 1986-2008, doi:10.1175/15200426(2002)019, 2002.

Ignatov, A., Minnis, P., Loeb, N., Wielicki, B., Miller, W., SunMack, S., Tanré, D., Remer, L., Laszlo, I., and Geier, E.: Two MODIS aerosol products over ocean on the Terra and Aqua CERES SSF datasets, J. Atmos. Sci., 62(4), 1008-1031, doi:10.1175/JAS3383.1, 2005.

IPCC: Climate Change 2007: The Science Basis, Cambridge Univ. Press, New York, 870 pp, 2007.

Jeong, M.-J. and Li, Z.: Quality, compatibility and synergy analyses of global aerosol products derived from the Advanced Very High Resolution Radiometers and Total Ozone Mapping Spectrometers, J. Geophy. Res., 110, D10S08, doi:10.1029/2004JD00464, 2005.

Jeong, M. J., Li, Z., Chu, D. A., and Tsay, S.-T.: Quality and compatibility analyses of global aerosol products derived from the Advanced Very High Resolution Radiometers and the Moderate Imaging Spectroradiometer, J. Geophy. Res., 110, D10S09, doi:10.1029/2004JD004648, 2005.

Kahn, R., Banerjee, P., and McDonald, D.: Sensitivity of multiangle imaging to natural mixtures of aerosols over oceans, J. Geophys. Res., 106(D16), 18219-18238, 2001.

Kahn, R., Gaitley, B., Martonchik, J., Diner, D. J., Crean, C. A., and Holben, B.: Multiangle Imaging Spectroradiometer (MISR) global aerosol optical depth validation based on 2 years of coincident Aerosol Robotic Network (AERONET) observation, J. Geophys. Res., 110, D10S04, doi:10.1029/2004JD004706, 2005a.

Kahn, R., Li, W.-H., Martonchik, J., Bruegge, C., Diner, D., Gaitley, B., Abdou, W., Dubovik, O., Holben, B., Smirnov, S., Jin, Z., and Clark, D.: MISR low-light-level calibration, and implications for aerosol retrieval over dark water, J. Atmos. Sci., 62(4), 10321062, doi:10.1175/JAS3390.1, 2005b.

Kahn, R., Garay, M., Nelson, D., Yau, K., Bull, M., and Martonchik, J.: Satellite-derived aerosol optical depth over dark water from MISR and MODIS: Comparisons with AERONET and implications for climatological studies, J. Geophys. Res., 112, D18205, doi:10.1029/2006JD008175, 2007.

Kalashnikova, O. V. and Kahn, R.: Ability of multi-angle remote sensing observations to identify and distinguish mineral dust types: Part 2. Sensitivity data analysis, J. Geophys. Res., 111(D11), D11207, doi:10.1029/2005JD006756, 2006.

Kaufman, Y. J., Tanré, D., Remer, L. A., Vermote, E. F., Chu, A., and Holben, B. N.: Operational remote sensing of tropospheric aerosol over land from EOS moderate resolution imaging spec- 
troradiometer, J. Geophys. Res., 102(D14), 17051-17067, 1997.

Kaufman, Y. J., Tanré, D., and Boucher, O.: A satellite view of aerosols in the climate system, Nature, 419, 215-223, doi:10.1038/nature01091, 2002.

Kaufman, Y. J., Remer, L. A., Tanré, D., Li, R.-R., Kleidman, R., Mattoo, S., Levy, R., Eck, T., Holben, B. N., Ichoku, C., Martins, V., and Koren, I.: A critical examination of the residual cloud contamination and diurnal sampling effects on MODIS estimates of aerosol over ocean, IEEE Trans. Geosci. Remote Sens., 43(12), 2886-2897, doi:10.1109/TGRS.2005.858430, 2005.

Kokhanovsky, A. A., Breon, F. M., Cacciari, A., Carboni, E., Diner, D., Di Nicolantonio, W., Grainger, R. G., Grey, W. M. F., Höller, R., Lee, K. H., Li, Z., North, P. R. J., Sayer, A., Thomas, G., and von Hoyningen-Huene, W.: Aerosol remote sensing over land: satellite retrievals using different algorithms and instruments, Atmos. Res., 85(3-4), 372-394, doi:10.1016/j.atmosres.2007.02.008, 2007.

King, D. M., Kaufman, Y. J., Tanre, D., and Nakajima, T.: Remote sensing of tropospheric aerosols from space: past, present, and future, B. Am. Meterol. Soc., 80(11), 2229-2259, doi:10.1175/1520-0477(1999)080, 1999.

Kinne, S., Schulz, M., Textor, C., Guibert, S., Balkanski, Y., Bauer, S. E., Berntsen, T., Berglen, T. F., Boucher, O., Chin, M., Collins, W., Dentener, F., Diehl, T., Easter, R., Feichter, J., Fillmore, D., Ghan, S., Ginoux, P., Gong, S., Grini, A., Hendricks, J., Herzog, M., Horowitz, L., Isaksen, I., Iversen, T., Kirkevåg, A., Kloster, S., Koch, D., Kristjansson, J. E., Krol, M., Lauer, A., Lamarque, J. F., Lesins, G., Liu, X., Lohmann, U., Montanaro, V., Myhre, G., Penner, J., Pitari, G., Reddy, S., Seland, O., Stier, P., Takemura, T., and Tie, X.: An AeroCom initial assessment - optical properties in aerosol component modules of global models, Atmos. Chem. Phys., 6, 1815-1834, 2006,

http://www.atmos-chem-phys.net/6/1815/2006/.

Kinne, S.: Remote sensing data combinations: Superior global maps for aerosol optical depth, in: Satellite Aerosol Remote Sensing Over Land, edited by: Kokhanovsky, A. A. and de Leeuw, G., Springer, Berlin, 2009.

Lee, K.-H., Li, Z., Wong, M.-S., Xin, J., Hao, W.-M., and Zhao, F.: Aerosol single scattering albedo estimated across China from a combination of ground and satellite measurements, J. Geophys. Res., 112, D22S15, doi:10.1029/2007JD009077, 2007.

Lee, K. H., Li, Z., Kim, Y. J., and Kokhanovsky, A.: Aerosol monitoring from satellite observations: a history of three decades, Atmospheric and Biological Environmental Monitoring, edited by: Kim, Y. J., Platt, U., Gu, M. B., and Iwahashi, H., Springer, 13-38, doi:10.1007/978-1-4020-9674-7, 2009.

Levy, R. C., Remer, L. A., and Dubovik, O.: Global aerosol optical properties and application to MODIS aerosol retrieval over land, J. Geophys. Res., 112, D13210, doi:10.1029/2006JD007815, 2007a.

Second-generation algorithm for retrieving aerosol properties over land from MODIS spectral reflectance, J. Geophys. Res., 112, D13211, doi:10.1029/2006JD007811, 2007b.

Levy, R. C., Remer, L. A., Martins, J. V., Kaufman, Y. J., PlanaFattori, A., Redemann, J., Russell, P. B., and Wenny, B.: Evaluation of the MODIS aerosol retrievals over ocean and land during CLAMS, J. Atmos. Sci., 62(4), doi:10.1175/JAS3391.1, 974992, 2005.

Levy, R. C., Remer, L. A., Tanré, D., Kaufman, Y. J., Ichoku, C.,
Holben, B. N., Livingston, J. M., Russell, P. B., and Maring, H.: Evaluation of the MODIS retrievals of dust aerosol over the ocean during PRIDE, J. Geophys. Res., 108(D19), 8594, doi:10.1029/2002JD002460, 2003.

Li, Z., Niu, F., Lee, K.-H., Xin, J., Hao, W.-M., Nordgren, B., Wang, Y., and Wang, P.: Validation and understanding of Moderate Resolution Imaging Spectroradiometer aerosol products (C5) using ground-based measurements from the handheld Sun photometer network in China, J. Geophys. Res., 112, D22S07, doi:10.1029/2007JD008479, 2007.

Liu, L., Mischenko, M., Geogdzhayev, I. V., Smirnov, A., Sakerin, S. M., Kabanov, D. M., and Ershov, O. A.: Global validation of two-channel AVHRR aerosol optical thickness retrievals over the oceans, J. Quant. Spectrosc. Radiat. Transfer, 88(1-3), 4759, doi:10.1016/j.jqsrt.2004.03.031, 2004.

Liu, L. and Mishchenko, M. I.: Toward unified satellite climatology of aerosol properties: direct comparisons of advanced level 2 aerosol products, J. Quant. Spectrosc. Radiat. Transfer, 109(14), 2376-2385, doi:10.1016/j.jqsrt.2008.05.003, 2008.

Luo, Y., Trishchenko, A. P., Latifovic, R., and Li, Z.: Surface bidirectional reflectance and albedo properties derived using a land cover-based approach with Moderate Resolution Imaging spectroradiometer observations, J. Geogphys. Res., 110, D01106, doi:10.1029/2004JD004741, 2005.

Martins, J. V., Remer, L., Kaufman, Y. J., Mattoo, S., and Levy, R.: MODIS cloud screening for remote sensing of aerosols over oceans using spatial variability, Geophys. Res. Lett., 29(12), 8009, doi:10.1029/2001GL013252, 2002.

Martonchik, J. V., Diner, D. J., Kahn, R., Ackerman, T. P., Verstraete, M. M., Pinty, B., and Gordon, H. R.: Techniques for the retrieval of aerosol properties over land and ocean using multiangle imaging, IEEE Trans. Geosci. Rem. Sens., 36(4), 12121227, doi:10.1109/36.701027, 1998.

Martonchik, J. V., Diner, D. J., Kahn, R. A., Gaitley, B. J., and Holben, B. N.: Comparison of MISR and AERONET aerosol optical depths over desert sites, Geophys. Res. Let., 31, L16101, doi:10.1029/2004GL019807, 2004.

Massie, T. S., Torres, O., and Smith, S. J.: Total Ozone Mapping Spectrometer observations of increases in Asian aerosol in winter from 1979 to 2000, J. Geophys. Res., 109, D18211, doi:10.1029/2004JD004620, 2004.

Mi, W., Li, Z., Xia, X., Holben, B., Levy, R., Zhao, F., Chen, H., and Cribb, M.: Evaluation of the Moderate Resolution Imaging Spectroradiometer aerosol products at two Aerosol Robotic Network stations in China, J. Geophys. Res., 112, D22S08, doi:10.1029/2007JD008474, 2007.

Mishchenko, M. I., Geogdzhayev, I. V., Cairns, B., Rossow, W. B., and Lacis, A.: Aerosol retrievals over the oceans by use of channels 1 and 2 AVHRR data: Sensitivity analysis and preliminary results, Appl. Optics, 38(36), 7325-7341, doi:10.1364/AO.38.007325, 1999.

Mishchenko, M. I., Geogdzhayev, I. V., Liu, L., Ogren, J. A., Lacis, A. A., Rossow, W. B., Hovenier, J. W., Volten, H., and Muñoz, O.: Aerosol retrievals from AVHRR radiances: effects of particle nonsphericity and absorption and an updated longterm global climatology of aerosol properties, J. Quant. Spectrosc. Radiat. Transfer, 79-80(1), 953-972, doi:10.1016/S00224073(02)00331-X, 2003.

Mishchenko, M. I., Geogdzhayev, I. V., Cairns, B., Carlson, B. 
E., Chowdhary, J., Lacis, A. A., Liu, L., Rossow, W. B., and Travis, L. D.: Past, present, and future of global aerosol climatologies derived from satellite observations: a perspective, J. Quant. Spectrosc. Radiat. Transfer, 106(1-3), 325-347, doi:10.1016/j.jqsrt.2007.01.007, 2007a.

Mishchenko, M. I., Geogdzhayev, I. V., Rossow, W. B., Cairns, B., Carlson, B. E., Lacis, A. A., Liu, L., and Travis, L. D.: Longterm satellite record reveals likely recent aerosol trend, Science, 315, 1543, 2007b.

Mishchenko, M. I. and Geogdzhayev, I. V.: Satellite remote sensing reveals regional tropospheric aerosol trends, Opt. Express, 15(12), 7423-7438, doi:10.1364/OE.15.007423, 2007c.

Mishchenko, M. I., Cairns, B., Kopp, G., Schueler, C. F., Fafaul, B. A., Hansen, J. E., Hooker, R. J., Itchkawich, T., Maring, H. B., and Travis, L. D.: Accurate monitoring of terrestrial aerosols and total solar irradiance: introducing the Glory Mission, B. Am. Meteorol. Soc., 88(5), 677-691, doi:10.1175/BAMS-88-5-677, 2007d.

Mishchenko, M. I., Geogdzhayev, I. V., Liu, L., Lacis, A. A., Cairns, B., and Travis, L. D.: Toward unified satellite climatology of aerosol properties: What do fully compatible MODIS and MISR aerosol pixels tell us?, J. Quant. Spectrosc. Radiat. Transfer, 110(6-7), 402-408, doi:10.1016/j.jqsrt.2009.01.007, 2009.

Myhre, G., Stordal, F., Johnsrud, M., Ignatov, A., Mishchenko, M. I., Geogdzhayev, I. V., Tanré, D., Deuzé, J.-L., Goloub, P., Nakajima, T., Higurashi, A., Torres, O., and Holben, B. N.: Intercomparison of satellite retrieved aerosol optical depth over the ocean, J. Atmos. Sci., 61(5), 499-513, doi:10.1175/15200469(2004)061, 2004.

Myhre, G., Stordal, F., Johnsrud, M., Diner, D. J., Geogdzhayev, I. V., Haywood, J. M., Holben, B. N., Holzer-Popp, T., Ignatov, A., Kahn, R. A., Kaufman, Y. J., Loeb, N., Martonchik, J. V., Mishchenko, M. I., Nalli, N. R., Remer, L. A., SchroedterHomscheidt, M., Tanré, D., Torres, O., and Wang, M.: Intercomparison of satellite retrieved aerosol optical depth over ocean during the period September 1997 to December 2000, Atmos. Chem. Phys., 5, 1697-1719, 2005,

http://www.atmos-chem-phys.net/5/1697/2005/.

Ramaswamy, V., Boucher, O., Haigh, J., Hauglustaine, D., Haywood, J., Myhre, G., Nakajima, T., Shi, G. Y., Solomon, S., et al.: Radiative forcing of climate change, in: Climate Change 2001; The Scientific Basis, edited by: Houghton, J. T., Ding, Y., and Griggs, D. J., ch. 6, pp 349-416, Cambridge University Press, New York, 2001.

Remer, L. A., Tanre, D., Kaufman, Y. J., Ichoku, C., Mattoo, S., Levy, R., Chu, D. A., Holben, B. N., Dubovik, O., Smirnov, A., Martins, J. V., Li, R.-R., and Ahmad, Z.: Validation of MODIS aerosol retrieval over ocean, Geophys. Res. Lett., 29(12), 8008, doi:10.1029/2001GL013204, 2002.

Remer, L. A., Kaufman, Y. J., Tanre, D., Mattoo, S., Chu, D. A., Martins, J. V., Li, R.-R., Ichoku, C., Levy, R. C., Kleidman, R. G., Eck, T. F., Vermote, E., and Holben, B. N.: The MODIS Aerosol Algorithm, Products and Validation, J. Atmos. Sci., 62(4), 947-973, doi:10.1175/JAS3385.1, 2005.

Remer, L. A., Kleidman, R. G., Levy, R. C., Kaufman, Y. J., Tanré, D., Mattoo, S., Martins, J. V., Ichoku, C., Koren, I., Yu, H., and Holben, B. N.: Global aerosol climatology from the MODIS satellite sensors, J. Geophys. Res., 113, D14S07, doi:10.1029/2007JD009661.
Robinson, W. D., Franz, B. A., Patt, F. S., Bailey, S. W., and Werdell, P. J.: Masks and flags updates, NASA Goddard Space Flight Center, Greenbelt, Maryland, SeaWiFS Postlaunch Technical Report Series Vol. 22, NASA Tech. Memo. 2003-206892, edited by: Hooker, S. B. and Firestone, E. R., 2003.

Rossow, W. B. and Garder, L. C.: Cloud detection using satellite measurements of infrared and visible radiances for ISCCP, J. Climate, 6(12), 2341-2369, doi:10.1175/1520-0442(1993)006, 1993.

Rossow, W. B. and Schiffer, R. A.: Advances in understanding clouds from ISCCP, B. Am. Meteorol. Soc., 80(11), 2261-2287, doi:10.1175/1520-0477(1999)080, 1999.

Siegel, D. A., Wang, M., Maritorena, S., and Robinson, W.: Atmospheric correction of satellite ocean color imagery: the black pixel assumption, Appl. Optics, 39(21), 3582-3591, doi:10.1364/AO.39.003582, 2000.

Smirnov, A., Holben, B. N., Kaufman, Y. J., Dubovik, O., Eck, T. F., Slutsker, I., Pietras, C., and Halthore, R.: Optical properties of atmospheric aerosol in maritime environments, J. Atmos. Sci., 59(3), 501-523, doi:10.1175/1520-0469(2002)059, 2002.

Smirnov, A., Holben, B. N., Dubovik, O., Frouin, R., Eck, T. F., and Slutsker, I.: Maritime component in aerosol optical models derived from Aerosol Robotic Network data, J. Geosphys. Res., 108(D1), 4033, doi:10,1029/2002JD002701, 2003.

Smirnov, A., Holben, B. N., Sakerin, S. M., Kabanov, D. M., Slutsker, I., Chin, M., Diehl, T. L., Remer, L. A., Kahn, R., Ignatov, A., Liu, L., Mishchenko, M., Eck, T. F., Kucsera, T. L., Giles, D., and Kopelevich, O. V.: Ship-based aerosol optical depth measurements in the Atlantic Ocean: comparison with satellite retrievals and GOCART model, Geophys. Res. Lett., 33, L14817, doi:10.1029/2006GL026051, 2006.

Stowe, L. L., Jacobowitz, H., Ohring, G., Knapp, K. R., and Nalli, N. R.: The Advanced Very High Resolution Radiometer (AVHRR) Pathfinder Atmosphere (PATMOS) climate dataset: initial analyses and evaluations, J. Climate, 15(11), 1243-1260, doi:10.1175/1520-0442(2002)015, 2002.

Stowe, L. L., Davis, P. A., and McClain, E. P.: Scientific basis and initial evaluation of the CLAVR-1 global clear/cloud classification algorithm for the Advanced Very High Resolution Radiometer, J. Atmos. Oceanic Technol., 16(6), 656-681, doi:10.1175/1520-0426(1999)016, 1999.

Stowe, L. L., Ignatov, A. M., and Singh, R. R.: Development, validation and potential enhancements to the second generation operational aerosol product at NOAA/NESDIS, J. Geophys Res., 102(D14), 16923-16934, 1997.

Stumpf, R. P., Arnone, R. A., Gould, R. W., Martinolich, P. M., and Ransibrahmanakul, V.: A partially coupled ocean-atmosphere model for retrieval of water-leaving radiance from SeaWiFS in coastal waters, Vol. 22, NASA Tech. Memo. 2003-206892, edited by: Hooker, S. B. and Firestone, E. R., SeaWiFS Postlaunch Technical Report Series, NASA Goddard Space Flight Center, Greenbelt, Maryland, p. 51-59, 2003.

Takemura, T., Nakajima, T., Dubovik, O., Holben, B. N., and Kinne, S.: Single scttering albedo and radiative forcing of various aerosol species with a three-dimensional model, J. Climate, 15(4), 333-352, doi:10.1175/1520-0442(2002)015, 2002.

Tanré, D., Kaufman, Y. J., Herman, M., and Mattoo, S.: Remote sensing of aerosol properties over oceans using the MODIS/EOS spectral radiances, J. Geophys. Res., 102(D14), 16971-16988, 
1997.

Torres, O., Bhartia, P. K., Herman, J. R., Ahmad, Z., and Gleason, J.: Derivation of aerosol properties from satellite measurements of backscattered ultraviolet radiation: Theoretical basis, J. Geophys. Res., 103(D14), 17099-17110, 1998.

Torres, O., Bhartia, P. K., Herman, J. R., Sinyuk, A., Ginoux, P., and Holben, B.: A long-term record of aerosol optical depth from TOMS observations and comparison to AERONET measurements, J. Atmos. Sci., 59(3), 398-413, doi:10.1175/15200469(2002)059, 2002.

Wang, M., Knobelspiesse, K. D., and McClain, C. R.: Study of the Sea-Viewing Wide Field-of-View Sensor (SeaWiFS) aerosol optical property data over ocean in combination with the ocean color products, J. Geophys. Res., 110, D10S06, doi:10.1029/2004JD004950, 2005.

Wang, M. and Shi, W.: Estimation of ocean contribution at the MODIS near-infrared wavelengths along the east coast of the U.S.: Two case studies, Geophys. Res. Lett., 32, L13606, doi:13610.11029/12005GL022917, 2005.

Wang, M.: Aerosol polarization effects on atmospheric correction and aerosol retrievals in ocean color remote sensing, Appl. Optics, 45(35), 8951-8963, doi:10.1364/AO.45.008951, 2006.

Wang, M., Tang, J., and Shi, W.: MODIS-derived ocean color products along the China east coastal region, Geophys. Res. Lett., 34, L06611, doi:10.1029/2006GL028599, 2007.

Yu, H., Kaufman, Y. J., Chin, M., Feingold, G., Remer, L. A., Anderson, T. L., Balkanski, Y., Bellouin, N., Boucher, O., Christopher, S., DeCola, P., Kahn, R., Koch, D., Loeb, N., Reddy, M. S., Schulz, M., Takemura, T., and Zhou, M.: A review of measurement-based assessments of the aerosol direct radiative effect and forcing, Atmos. Chem. Phys., 6, 613-666, 2006, http://www.atmos-chem-phys.net/6/613/2006/.

Zhang, J., Christopher, S. A., Remer, L. A., and Kaufman, Y. J.: Shortwave aerosol radiative forcing over cloud-free oceans from Terra: 2. Seasonal and global distributions, J. Geophys. Res., 110, D10S24, doi:10.1029/2004JD005009, 2005b.
Zhao, X., Stowe, L. L., Smirnov, A., Crosby, D., Sapper, J., and McClain, C. R.: Development of a global validation package for satellite oceanic aerosol optical thickness retrieval based on AERONET observations and its applications to the NOAA/NESDIS operational aerosol retrievals, J. Atmos. Sci., 59(3), 294-312, doi:10.1175/1520-0469(2002)059, 2002.

Zhao, X., Laszlo, I., Holben, B. N., Pietras, C., and Voss, K. J.: Validation of two-channel VIRS retrievals of aerosol optical thickness over ocean and quantitative evaluation of the impact from potential sub-pixel cloud contamination and surface wind effect, J. Geophys. Res., 108(D3), 4106, doi:10.1029/2002JD002346, 2003.

Zhao, X., Dubovik, O., Smirnov, A., Holben, B. N., Sapper, J., Pietras, C., Voss, K. J., and Frouin, R.: Regional evaluation of an advanced very high resolution radiometer (AVHRR) two-channel aerosol retrieval algorithm, J. Geophys. Res., 109, D02204, doi:10.1029/2003JD003817, 2004.

Zhao, X., Laszlo, I., Minnis, P., and Remer, L.: Comparison and analysis of two aerosol retrievals over the ocean in the Terra/CERES-MODIS Single Scanner Footprint (SSF) data: Part-I - Global evaluation, J. Geophys. Res., 110, D21208, doi:10.1029/2005JD005851, 2005a.

Zhao, X., Laszlo, I., Minnis, P., and Remer, L.: Comparison and analysis of two aerosol retrievals over the ocean in the Terra/CERES-MODIS Single Scanner Footprint (SSF) data: Part-II - Regional evaluation, J. Geophys. Res., 110, D21209, doi:10.1029/2005JD005852, 2005b.

Zhao, T. X.-P., Yu, H., Laszlo, I., Chin, M., and Conant, W. C.: Derivation of component aerosol direct radiative forcing at the top of atmosphere for clear-sky ocean, J. Quant. Spectrosc. Radiat. Transfer, 109(7), 1162-186, doi:10.1016/j.jqsrt.2007.10.006, 2008a.

Zhao, T. X.-P., Laszlo, I., Guo, W., Heidinger, A., Cao, C., Jelenak, A., Tarpley, D., and Sullivan, J.: Study of long-term trend in aerosol optical thickness observed from operational AVHRR satellite instrument, J. Geophys. Res., 113, D07201, doi:10.1029/2007JD009061, 2008b. 